\title{
Level of Macronutrients and Microelements of Blood Plasma in Different Forms of Pulmonary Tuberculosis
}

\section{Larisa Obukhova1, Elena Erlykina1, Amir Aliyev², Rafig Chobanov², Vladimir Pimenov3, Ilya Evdokimov ${ }^{3}$, Aliyar Sarvarov ${ }^{4}$}

${ }^{1}$ FSBEI of Higher Education "Nizhny Novgorod State Medical Academy” of the Ministry of Health of the Russian Federation, Nizhny Novgorod, Russia

${ }^{2}$ Azerbaijan Medical University, Baku, Azerbaijan

${ }^{3}$ FPFIS G.G. Devyatykh Institute of Chemistry of High-Purity Substances of RAS, Nizhny Novgorod, Russia

${ }^{4}$ Guba District Central Hospital, Guba, Azerbaijan

Email: amirvugar@mail.ru

How to cite this paper: Obukhova, L., Erlykina, E., Aliyev, A., Chobanov, R., Pimenov, V., Evdokimov, I. and Sarvarov, A. (2017) Level of Macronutrients and Microelements of Blood Plasma in Different Forms of Pulmonary Tuberculosis. Journal of Biosciences and Medicines, 5, 81-87.

https://doi.org/10.4236/jbm.2017.512009

Received: November 9, 2017

Accepted: December 11, 2017

Published: December 14, 2017

Copyright $\odot 2017$ by authors and Scientific Research Publishing Inc. This work is licensed under the Creative Commons Attribution International License (CC BY 4.0).

http://creativecommons.org/licenses/by/4.0/

\begin{abstract}
By the method of atomic emission spectrometry with inductively coupled plasma, the content of macro and microelements in the blood plasma of 35 practically healthy people living in the Northern region of Azerbaijan and in the Nizhny Novgorod region of the Russian Federation was studied as well as of 23 patients with pulmonary tuberculosis with different phases of the disease. The elemental homeostasis of the blood plasma did not significantly differ depending on the region of residence, except for the potassium level (by 1.3 times greater for Russians) and strontium (by 10 times higher among the inhabitants of the Northern region of Azerbaijan). In patients with focal pulmonary tuberculosis, there were no significant differences in the content of elements in the blood plasma. With pulmonary tuberculosis, accompanied by decomposition processes, the content of calcium, copper, zinc and iron in blood plasma significantly increases in comparison with healthy people. Analysis of the level of these macro- and microelements can be used to determine the transition of the early form of pulmonary tuberculosis to infiltrative and/or cavernous forms, in which the patient becomes epidemiologically dangerous to others.
\end{abstract}

\section{Keywords}

Pulmonary Tuberculosis, Focal Form, Cavernous Form, Macroelements, Microelements, Calcium, Copper, Zinc, Iron 


\section{Introduction}

Radiation imaging techniques, bacterioscopy, cultural and genetic differential methods are used to diagnose pulmonary tuberculosis [1], but often all of the above does not allow us to identify this pathology in the early stages. An important clinical significance in the treatment of pulmonary tuberculosis is the evaluation of the effectiveness of the therapy. It is important to keep track of the transition of the early form of pulmonary tuberculosis to infiltrative and/or cavernous forms of pulmonary tuberculosis, in which the patient becomes potentially epidemiologically dangerous to others, effectively becoming an active tuberculosis focus. It is known that the level of micro- and macronutrients in blood plasma varies significantly with various diseases [2]. However, the available literature data on the violation of elemental homeostasis of blood plasma in pulmonary tuberculosis are quite contradictory [3] [4]. In addition, since the average values of the content of micro- and macronutrients in practically healthy people living in different regions may differ, it is necessary to rely on the values of the norm for a particular area of residence.

In connection with the foregoing, the purpose of this study was a comparative analysis of the level of macro and microelements of blood plasma of practically healthy people living in Azerbaijan and Russia, and an assessment of the violations of the mineral homeostasis of blood plasma in various forms of pulmonary tuberculosis.

\section{Material and Methods}

Investigation was carried out in April 2016. Blood plasma was studied in 35 practically healthy people living in the Northern rural region of Azerbaijan (Guba district) (15 people aged $33-60$ ) and living in the Nizhny Novgorod region of the Russian Federation (20 people 29 - 58 years), comparable in gender and age. Blood samples were also analyzed for 23 patients who had not previously undergone anti-tuberculosis treatment: 16 men ( 16 - 57 years) and 7 women (34 - 56 years) living in Guba district of Azerbaijan. 60\% of patients were characterized by a far-reaching tuberculosis process in the phase of decay: infiltrative and cavernous forms. $40 \%$ of patients had one- or two-sided focal pulmonary tuberculosis.

Analysis of the level of macro- and microelements was carried out using atomic-emission spectrometry with inductively coupled plasma on an iSAP6300Duo spectrometer (Thermo Scientific, the USA). Statistical processing of the results was carried out using the BIOSTAT software package. When assessing the array of data on the biochemical parameters of patients using the Shapiro-Wilk test, the normality of the distribution was not confirmed, and that is why the non-parametric statistics methods were used to assess the significance of differences with the control group: Mann-Whitney and Kolmogorov-Smirnov tests.

\section{Results and Discussion}

When comparing the data on the elemental homeostasis of the blood plasma of 
practically healthy people living in Azerbaijan and the Russian Federation, a statistically significant difference in the level of potassium (almost by 1.3 times greater among Russians) and strontium (by 10 times higher among residents of the northern region of Azerbaijan) (Table 1). On the other investigated parameters, there were no reliable differences.

In patients with pulmonary tuberculosis, the levels of calcium, copper, iron and zinc in the blood significantly increased (Table 1).

Different forms of tuberculosis differ in their biochemical and physiological characteristics, and that is why a comparative analysis of the level of micro- and macronutrients in the blood plasma of patients with initial and infiltrative, cavernous forms was carried out. It was shown that with pulmonary tuberculosis accompanied by decomposition processes, the content of calcium, copper, zinc and iron in blood plasma significantly increases in comparison with healthy people, while in patients with focal pulmonary tuberculosis such a difference was not found (Figures 1(a)-(d)).

There are known humoral compounds promoting the development of hypercalcemia: prostaglandins, transforming growth factors, a number of cytokines

Table 1. The content of macro- and microelements in blood plasma $(M \pm m)$ of practically healthy people from Azerbaijan and Russia and patients with pulmonary tuberculosis (Azerbaijan).

\begin{tabular}{|c|c|c|c|c|}
\hline & & $\begin{array}{l}\text { Actually healthy } \\
\text { people, Russia }\end{array}$ & $\begin{array}{l}\text { Actually healthy } \\
\text { people, Azerbaijan }\end{array}$ & $\begin{array}{l}\text { Patients with pulmonary } \\
\text { tuberculosis, Azerbaijan }\end{array}$ \\
\hline \multirow{4}{*}{ Macroelements } & $\mathrm{Na}, \mathrm{mkg} / \mathrm{ml}$ & $3400.50 \pm 58.00$ & $2800.00 \pm 100.00$ & $2860.00 \pm 40.00$ \\
\hline & $\mathrm{K}, \mathrm{mkg} / \mathrm{ml}$ & $1232.70 \pm 42.15$ & $940.34 \pm 34.64 \boldsymbol{\Delta}$ & $572.00 \pm 120.80$ \\
\hline & $\mathrm{Ca}, \mathrm{mkg} / \mathrm{ml}$ & $79.50 \pm 2.13$ & $89.67 \pm 3.18$ & $93.40 \pm 1.86^{*}$ \\
\hline & $\mathrm{Mg}, \mathrm{mkg} / \mathrm{ml}$ & $16.5 \pm 0.98$ & $24.33 \pm 1.85$ & $22.80 \pm 0.37$ \\
\hline \multirow{13}{*}{ Microelements } & $\mathrm{Al}, \mathrm{mkg} / \mathrm{ml}$ & $<0.2$ & $<0.2$ & $<0.2$ \\
\hline & $\mathrm{Ba}, \mathrm{mkg} / \mathrm{ml}$ & $<0.04$ & $<0.04$ & $<0.04$ \\
\hline & $\mathrm{Co}, \mathrm{mkg} / \mathrm{ml}$ & $<0.06$ & $<0.06$ & $<0.06$ \\
\hline & $\mathrm{Cr}, \mathrm{mkg} / \mathrm{ml}$ & $<0.04$ & $<0.04$ & $<0.04$ \\
\hline & $\mathrm{Cu}, \mathrm{mkg} / \mathrm{ml}$ & $0.95 \pm 0.09$ & $0.87 \pm 0.06$ & $1.23 \pm 0.93^{*}$ \\
\hline & $\mathrm{Fe}, \mathrm{mkg} / \mathrm{ml}$ & $1.21 \pm 0.08$ & $1.05 \pm 0.05$ & $1.46 \pm 0.11^{*}$ \\
\hline & $\mathrm{Li}, \mathrm{mkg} / \mathrm{ml}$ & $<0.04$ & $<0.04$ & $<0.04$ \\
\hline & $\mathrm{Ni}, \mathrm{mkg} / \mathrm{ml}$ & $<0.1$ & $<0.1$ & $<0.1$ \\
\hline & $\mathrm{Se}, \mathrm{mkg} / \mathrm{ml}$ & $<0.7$ & $<0.7$ & $<0.7$ \\
\hline & $\mathrm{Sr}, \mathrm{mkg} / \mathrm{ml}$ & $0.06 \pm 0.006$ & $0.62 \pm 0.16 \boldsymbol{\Delta}$ & $0.88 \pm 0.31$ \\
\hline & $\mathrm{V}, \mathrm{mkg} / \mathrm{ml}$ & $<0.1$ & $<0.1$ & $<0.1$ \\
\hline & $\mathrm{Zn}, \mathrm{mkg} / \mathrm{ml}$ & $0.56 \pm 0.01$ & $0.69 \pm 0.07$ & $1.60 \pm 0.57^{\star}$ \\
\hline & $\mathrm{Mo}, \mathrm{mkg} / \mathrm{ml}$ & $<0.07$ & $<0.07$ & $<0.07$ \\
\hline
\end{tabular}

$\mathbf{\Delta}$ : differences with indicators of practically healthy people living in Russia are reliable $(\mathrm{p}<0.05)$; ${ }^{*}$ : differences with the parameters of the control group (practically healthy people living in Azerbaijan) are reliable $(\mathrm{p}<0.05)$. 
(a) Concentration of calcium in blood plasma, $\mathrm{mcg} / \mathrm{ml}$

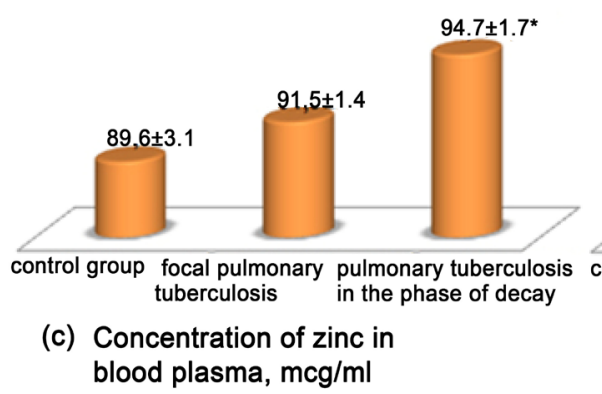

(b) Concentration of copper in blood plasma, $\mathrm{mcg} / \mathrm{ml}$

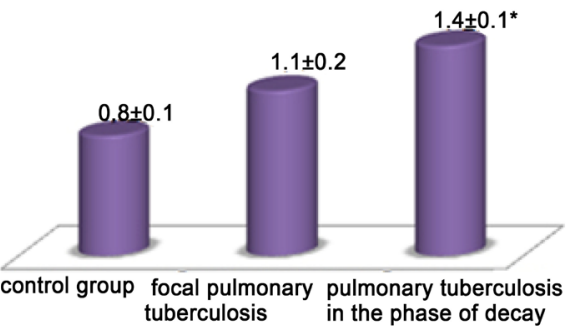

(d) Concentration of iron in blood plasma, $\mathrm{mcg} / \mathrm{ml}$

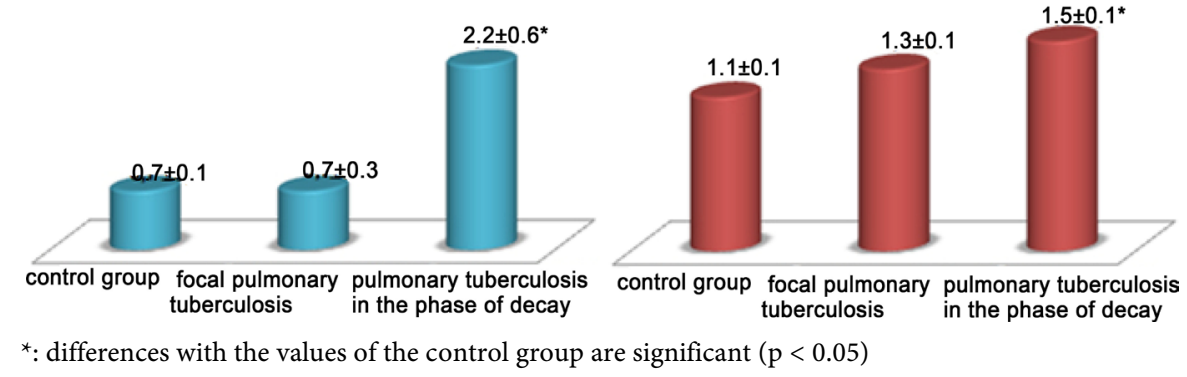

Figure 1. The level of calcium, copper, zinc, iron $(\mathrm{M} \pm \mathrm{m})$ in the blood plasma of patients with various forms of pulmonary tuberculosis. The control group is practically healthy people who also live in the northern region of Azerbaijan.

(IL-1, IL-4, IL-6, TNF-alpha and TNF- $\beta$ ), which function due to activation of osteoclasts [5]. In the analysis of 23,500 proteins of human proteome, it was found that the functions of 2145 proteins depend to some extent on the level of calcium in the body (for example, the levels of protein expression change), and 625 of the 2145 proteins directly bind the $\mathrm{Ca}^{2+}$ ion as a cofactor. In addition, calcium ions take a significant part in the processes of intercellular adhesion and formation of the structure of connective tissue, regulation of cellular apoptosis and inflammation [6]. Calcium can probably play a regulating role in the destruction of lung tissue, as it participates in the activation of $\mathrm{Ca}^{2+}$ dependent proteases and phospholipases, as well as its pro-oxidative effect of calcium [7].

According to modern ideas [4], an increase in the concentration of copper in pulmonary tuberculosis is compensatory, which is associated with its antimicrobial effect [8]. Copper is also needed for the synthesis of various connective tissue derivatives (since it participates in the copper-dependent enzyme lysyloxidase, which catalyzes the conversion of collagen amino groups of lysyl residues to aldehyde groups that stabilize collagen fibrils), possibly explaining the activation of sclerotic processes in lung tissue in pulmonary tuberculosis. Copper is a part of ceruloplasmin, which is one of the active enzymes of antioxidant protection, an endogenous modulator of inflammatory processes. In addition, copper (as well as $\mathrm{Zn}^{2+}$ ) is part of the subunits of superoxide dismutase, which inhibits free radical processes in cells [7] [9] [10] [11] [12].

Iron is important not only for providing the body with oxygen (hemoglobin, myoglobin), but also for the functioning of the respiratory chain and the synthe- 
sis of ATP (cytochromes a, b, c), toxic detoxification processes (cytochrome P450), but also plays a role in immune reactions. Thus, iron is necessary for the activation of neutrophils and the realization of their functions, being a component of peroxygen-generating and nitroxide-generating enzymes, as well as an integral component of myeloperoxidase [13] [14] [15]. Iron is involved in the regulation of cytokine production, the synthesis of protein by lymphocytes [9]. All groups of protozoa, fungi, bacteria (other than non-pathogenic lactobacilli and Borrelia burgdorferi) need iron for their vital functions [16]. The binding of iron by transferrin and ferritin causes a decrease in bacterial growth [17]. An increase in the concentration of iron in the destructive forms of pulmonary tuberculosis is probably compensatory in nature, promoting the inactivation of toxic peroxide compounds, since iron is a constituent of catalase and peroxidase.

Zinc is involved in the processes of DNA synthesis and repair, tissue regeneration, immunogenesis, endocrine system functioning, etc. It is a competitive antagonist of calcium and magnesium, promoting endonuclease activity and prevents apoptosis [10]. Zinc is included with the composition of carbonic anhydrase, which catalyzes the hydration of carbon dioxide. The enzyme is necessary to maintain acid-alkaline homeostasis, respiration, calcification, bone resorption. Carbonic anhydrase with glycosylphosphatidylinositol is attached to the membrane of the pulmonary capillaries. There is evidence of the ability of $\mathrm{Zn}^{2+}$ to induce expression in lymphocytes of immunophilin proteins that protect cells from toxic effects and serve as immunogens for T-lymphocytes [11]. The role of zinc in potentiating cellular and humoral immunity directed against bacteria, viruses and tumor cells is shown. Zinc stimulates intrathymic development of T-lymphocytes, differentiation of B-lymphocytes into immunoglobulin-secreting cells through $\mathrm{Zn}^{2+}$-dependent finger-proteins [12], maturation of CD4 and CD8 lymphocytes in culture, expression of molecules of the main histocompatibility complex on macrophages. It regulates antigenigenesis, increases the activity of phagocytosis [18], stimulates the release of interleukin-2 and gamma-interferon. An increase in the concentration of zinc in the blood plasma for pulmonary tuberculosis can be explained by the inclusion of protective mechanisms that prevent free radical damage to cells, since zinc, as well as copper, is part of $\mathrm{Zn}$-Cu-superoxide dismutase. Zinc activates the release of tumor necrosis factor, which has a cytotoxic, cytostatic effect and the ability to activate necrosis [19].

The results obtained do not contradict the available literature data [4] [20], but in existing studies the level of macro- and microelements in the blood is compared with that of chronic obstructive pulmonary disease. A comparative analysis of elemental homeostasis of blood plasma with open and closed forms of pulmonary tuberculosis has not been performed previously. This study just started and presented to the Russian Patent Agency.

\section{Conclusion}

The revealed changes in the blood content of such elements as calcium, copper, iron, zinc cannot be used as an additional diagnostic sign for early detection of 
pulmonary tuberculosis, since at the early stage of this disease, no significant changes in their level in the blood are observed. The elemental homeostasis of the blood plasma did not significantly differ depending on the region of residence, except for the level of potassium (1.3 times greater for Russians) and strontium (10 times higher among the inhabitants of the northern region of Azerbaijan). However, the analysis of the level of the above macro- and microelements can be applied to determine the transition of the early form of pulmonary tuberculosis to infiltrative and/or cavernous forms of pulmonary tuberculosis, in which the disintegration of lung tissue occurs and the patient becomes epidemiologically dangerous to others.

\section{Acknowledgements}

The work was carried out at the expense of the regional government grant of the Nizhny Novgorod region (Russia) in the field of science and technology for 2016.

\section{References}

[1] Crofton, D., Khorn, N. and Miller, F. (2016) Clinic of Tuberculosis. Meditsina, Moscow, 199. [in Russian]

[2] Oberlis, D., Kharland, B. and Skalnyi, A. (2015) Biological Role of Macro- and Microelements in Humans and Animals. Nauka, Saint Petersburg, 544. [in Russian]

[3] Mohan, G., Kulshreshtha, S. and Sharma, P. (2006) Zinc and Copper in Indian Patients of Tuberculosis: Impact on Antitubercular Therapy. Biological Trace Element Research, 111, 63-69. https://doi.org/10.1385/BTER:111:1:63

[4] Novitskii, V.V., Strelis, A.K., Urazova, O.I., Shil'ko, T.A., Esimova, I.E., Voronkova, O.V., Sinitsina, V.A., Filinyuk, O.V., Ivanova, E.V., Baranova, O.V. and Tkachenko, S.B. (2016) Macro- and Microelements of Blood Mononuclear Cells in Patients with Pulmonary Tuberculosis. Mikroelementy v medicine, 7, 33-38. [in Russian]

[5] Niizuma, H., Fujii, K., Sato, A., Fujiwara, I., Takeyama, J. and Imaizumi, M. (2007) PTHrP-Independent Hypercalcemia with Increased Proinflammatory Cytokines and Bone Resorption in Two Children with CD19-Negative Precursor B Acute Lymphoblastic Leukemia. Pediatric Blood \& Cancer, 49, 990-993. https://doi.org/10.1002/pbc.20782

[6] Gromova, O.A., Torshin, I.Y., Grishina, T.R. and Lisitsa, A.V. (2013) Prospects for Using Preparations Based on Organic Calcium Salts. Molecular Mechanisms of Calcium. Lechashchii Vrach, 4, 42-44. [in Russian]

[7] Zenkov, N.K., Lankin, V.Z. and Men'shchikova, E.B. (2014) Oxidative Stress. Nauka, Moscow, 343. [in Russian]

[8] Publishing House M. (2015) All about Vitamins and Microelement. Praktika, Moscow, 382. [in Russian]

[9] Novikova, I.A. (2011) Iron and Immune Response. Problemy zdorov'ya i ekologii, 5, 42-48. [in Russian]

[10] Skal'nyi, A.V. (2013) Zinc and Human Health. RIK GOUOGU, Orenburg, 80. [in Russian]

[11] Kudrin, A.V. and Skal'nyi A.V. (2011) Microelements in Oncology. Part 2. Micro- 
elements and Antitumor Immunity. Mikroelementy v medicine, 2, 31-39. [in Russian]

[12] Hosea, H.J., Rector, E.S. and Taylor, C.G. (2003) Zinc-Deficient Rats Have Fewer Recent Thymic Emigrant $\left(\mathrm{CD}^{+}\right)$T Lymphocytes in Spleen and Blood. Journal of Nutrition, 133, 4239-4242.

[13] Oppenheimer, S.J. (2001) Iron and Its Relation to Immunity and Infectious Disease. Journal of Nutrition, 131, 616-635.

[14] Beard, J.L. (2001) Iron Biology in Immune Function, Muscle Metabolism and Neuronal Functioning. Journal of Nutrition, 131, 568-580.

[15] Ahluwalia, N., Sun, J., Krause, D., Mastro, A. and Handte, G. (2004) Immune Function Is Impaired in Irondeficient, Homebound, Older Women. American Journal of Clinical Nutrition, 79, 516-521.

[16] Bhaskaram, P. (2002) Micronutrient Malnutrition, Infection, and Immunity: An Overview. Nutrition Reviews, 60, 40-45. https://doi.org/10.1301/00296640260130722

[17] Kumar, V. and Choudhry, V.P. (2010) Iron Deficiency and Infection. Indian Journal of Pediatrics, 77, 789-793. https://doi.org/10.1007/s12098-010-0120-3

[18] Di Costanzo, L., Pique, M.E. and Christianson, D.W. (2007) Crystal Structure of Human Arginase I Complexed with Thiosemicarbazide Reveals an Unusual Thiocarbonly $\mu$-Sulfide Ligand in the Binuclear Manganese Cluster. Journal of the American Chemical Society, 129, 6388-6389. https://doi.org/10.1021/ja071567j

[19] Locksley, R.M., Killeen, N. and Lenardo, M.J. (2001) The TNF and TNF Receptor Superfamilies: Integrating Mammalian Biology. Cell, 104, 487-501. https://doi.org/10.1016/S0092-8674(01)00237-9

[20] Irfan, A., Srivastava, V.K., Prasad, R., Mohd, Y., Safia, Saleem M. and Wahid, A. (2011) Deficiency of Micronutrient Status in Pulmonary Tuberculosis Patients in North India. Biomedical Research, 22, 449-454. 